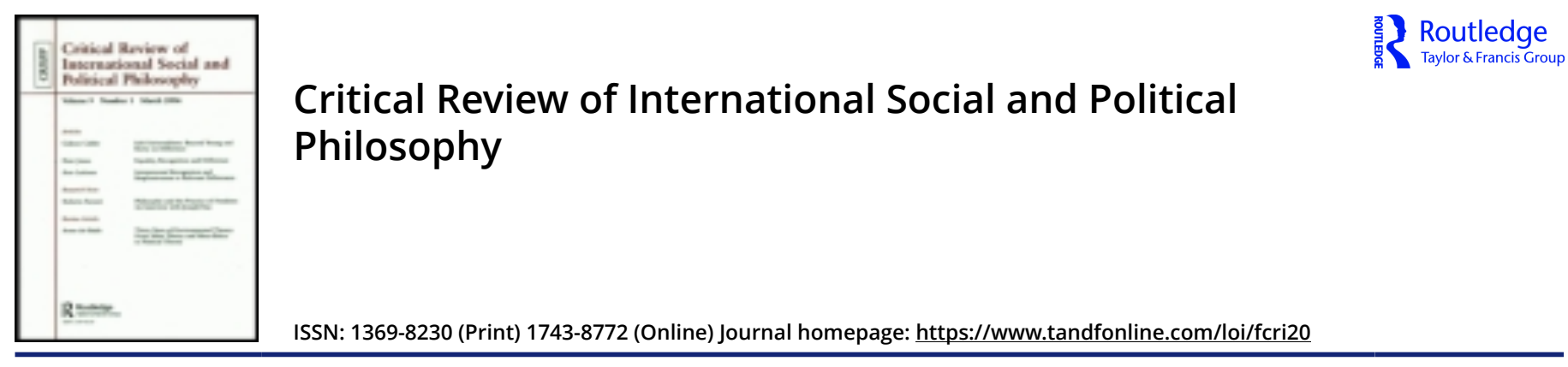

\title{
The people's duty
}

\section{Shmuel Nili}

To cite this article: Shmuel Nili (2020): The people's duty, Critical Review of International Social and Political Philosophy, DOI: 10.1080/13698230.2020.1744080

To link to this article: https://doi.org/10.1080/13698230.2020.1744080

Published online: 18 Mar 2020.

Submit your article to this journal ¿

!ll Article views: 13

Q View related articles $\square$

View Crossmark data $\longleftarrow$ 


\section{The people's duty}

\section{Shmuel Nili}

Political Science Department, Northwestern University, Evanston, IL, USA; School of Philosophy, the Australian National University, Canberra, Australia

The People's Duty develops two philosophical frameworks centered on the sovereign people in a liberal democracy as a collective agent. First, a collective integrity framework, conceiving of a liberal-democratic people as an agent with its own morally important integrity. Second, a collective property framework, revolving around a particular model of public property owned by the people.

In elaborating these frameworks, I seek theoretical as well as practical advances. At the theoretical level, individual integrity and property have been the subjects of influential philosophical literatures. But philosophers have had far less to say about these concepts' collective variants. The idea that the people as a collective agent can be the bearer of integrity has received scant philosophical attention. Similarly, there is a marked asymmetry between the vast philosophical literature on private property, and the extremely limited philosophical literature on property owned by the people as a collective agent. One key aim of the book's opening chapters is to show that rich theoretical dividends follow once we correct this comparative neglect of collective integrity and collective property.

The book's latter part is devoted to practical contributions. Here I seek to show that sustained reflection on the people's integrity and property advances our moral analysis of multiple real-world policy issues. Among other issues, the book takes up policy problems concerning the domestic and international dimensions of corruption and abuse of power. It examines policy questions concerning fragile transitions to democracy. And it delves into policy responses to ethnic and religious divides that threaten liberal democracy. In each of these contexts, I argue, the collective integrity and collective property frameworks yield significant practical payoffs.

The book's theoretical and practical contributions are linked through a particular understanding of what a 'moral framework' is. As the book's introduction explains, I deploy this term to refer to a set of moral values that have certain affinities to one another. A fruitful moral framework,

CONTACT Shmuel Nili Shmuel.nili@northwestern.edu

(c) 2020 Informa UK Limited, trading as Taylor \& Francis Group 
I suggest, is one that organizes the multiple values in such a way so as to allow us to do more with them, as a set, than we could do by invoking each particular value in isolation.

More specifically, I see a helpful moral framework as providing three main benefits, which run throughout the book. First, a compelling moral framework has what I call a 'unifying function': it adds to the unity of our moral outlook, whether by showing that certain apparent conflicts between our moral values are illusory, or by showing how seemingly disparate moral values can be brought together to form a unified whole. Second, by deepening our understanding of how some of our values fit together with others, a fruitful moral framework buttresses our confidence in all of them. This added confidence, in turn, should make us more willing to insist that the relevant values, as a set, should be prioritized when they truly conflict with countervailing moral considerations.

Finally, this 'adjudicating function' of a moral framework is accompanied by what I call an 'amplifying function': A compelling moral framework can help us to better organize our moral values by showing us when we ought to make special efforts to realize certain moral duties, and when it would be especially wrong of us not to fulfil these duties. This point is especially important in alltoo-common political circumstances where priorities have to be assigned among different collective ends, all of which are morally valuable.

The book illustrates these three contributions of a moral framework with reference to both the people's integrity and the people's property. In order to offer a more concrete sense of these contributions, I now introduce each of the book's chapters in a bit more detail. My hope is that, although inevitably compressed, the presentation will make clear how the book's theoretical and practical contributions stand together.

Chapter 1 keys off the familiar idea (associated with Bernard Williams) that an agent's integrity consists in the pursuit of identity-grounding projects. I argue that we should understand the core project of a liberal legal system - realizing equal rights - as the identity-grounding project of the collective agent that is the sovereign people, and thus as essential to the people's integrity. I explain how conceiving the realization of equal rights through the law as identity-grounding collective project helps us unify important moral intuitions concerning civic engagement in a liberal democracy, the moral authority of liberal law, and the place of struggles to realize equal rights in a liberal democracy's collective identity. Linking this project to what I term identity-grounding legal institutions, I show why threats to the coherence of these institutions - domestic and global constitute morally important threats to a liberal polity's integrity.

I pay particular attention to the threats posed by liberal entanglement in the activities of manifestly illiberal foreign regimes (for instance, profoundly 
racist or corrupt regimes). I argue that there are important instances (both real and hypothetical) where the moral reasons against such liberal entanglement cannot be captured through standard consequentialist reasoning, nor can these reasons be captured by directly invoking the rights, autonomy, or dignity of the victims of the relevant regimes. Instead, in some cases at least, the moral reasons against liberal entanglement in the nefarious activities of manifestly illiberal regimes are best understood as reasons of collective liberal integrity. These reasons point to a kind of collective self-betrayal, paralleling the self-betrayal an individual may experience when regularly pursuing actions that contradict her identity-grounding commitments. I accordingly argue that a liberal democracy has integrity reasons not to legitimate, perpetuate, or benefit from manifestly illiberal foreign practices that, were they enacted within its borders, would distort its identity-grounding institutions beyond recognition. These reasons of collective integrity, I further contend, have independent moral force, even if they can be outweighed (especially in tragic circumstances) by countervailing moral considerations.

Throughout the chapter, I show how my view of collective integrity can capture powerful intuitions as to how a liberal democracy's particular history can amplify the moral force of certain integrity reasons - explaining, for example, why a liberal democracy with a particularly loaded history of racial discrimination has especially weighty and stringent moral reasons against entanglement in the activities of racist foreign regimes. I also show how my account of liberal integrity connects with several other morally important values. The list includes values that are normally thought to have important affinities to integrity (such as steadfastness, honesty, avoidance of selfseeking rationalizations, and aversion to hypocrisy). But it also includes values whose relationship to integrity may initially seem more obscure, such as decency.

Chapter 2 turns from the people's integrity to the people's property. Despite the centrality of public property to virtually any functioning state and economy, and despite an extensive philosophical literature on private property, normative political theory has long lacked a compelling liberal account of public property. Tackling this gap, I show why we cannot understand public property as simply the aggregation of private holdings. I ultimately settle on an opposite view: seeing private property as derived from public holdings. On the 'deep public ownership' model that I defend, the sovereign people's moral power to create private property rights through the legal system is intertwined with a moral claim to be the ultimate owner of all the resources within its jurisdiction.

While heterodox, this model meets multiple crucial desiderata. It captures firm-but-difficult-to-ground convictions regarding theft of public property by de-facto rulers. It is compatible with liberal intuitions regarding the significance of private property. It can explain (unlike the private aggregation view) 
why uncoordinated activities of individual citizens acting as private persons cannot alter the status of public property. And finally, the model renders more unified our thinking about the demands of equality, by showing that private property rights do not constrain anti-discriminatory government policies.

I end chapter 2 by motivating my pragmatic assumptions regarding the composition of 'the sovereign people' that owns public property. I explain why I treat stable international borders as demarcating rightful territories, and why I take all of the individuals who permanently reside within each of these territories as those who ought to comprise - at least on first approximation - the different sovereign peoples who make collective property claims within each of these territories. I also show how this pragmatic orientation, notwithstanding its 'statist' elements, is fully compatible with a 'cosmopolitan' view of who may become a member of the people through immigration, and thus come to share both in the people's collective project of realizing equal rights, and in the people's ownership of public property.

Chapter 3 moves the discussion from philosophical foundations to concrete politics. Here I take up for the first time a classic fear - running throughout the remainder of the book - regarding any talk of 'the people' as a unified collective agent. The fear is that real-world politics revolves around division rather than unity. I, therefore, begin my applied discussion by showing how my collectivist frameworks can illuminate the quintessential political divide, between ordinary citizens and those who wield de-facto power. More specifically, I combine the collective property and integrity frameworks to elucidate understudied moral dilemmas concerning special legal protections of those who wield de-facto political power, and these protections' relationship to corruption and abuse of power.

In the chapter's first part, I discuss the practice of formally shielding senior members of an elected government from the ordinary reach of the law. I argue that in normal circumstances, the possibility that this practice will facilitate more effective government is outweighed by the core value of equality before the law, without which no people can succeed in the collective project of realizing equality through the law. I then turn to morally abnormal circumstances, such as those that obtained in Italy in the early 1990s and have been unfolding in Brazil over the last few years, where virtually all experienced politicians turn out to be implicated in serious corruption. In such circumstances, pursuing the full extent of the law against all suspected politicians poses real risk to basic political and economic stability. Taking these risks seriously, I suggest that the people, as the owners of the public property that has been abused by the corrupt, should decide through a referendum whether to grant - under these emergency circumstances - temporary executive immunity to the accused. I use the collective 
integrity framework yet again - and primarily its emphasis on a steadfast commitment to equality before the law - to refine this referendum proposal.

The latter part of chapter 3 turns to other abuses of power, and other measures shielding senior public figures from the law. I start with the practice of pardons, since pardons can be both a response to past abuses of power and themselves be abused by those wield the power to issue them. I show that pardons can normally be condemned using both collective integrity and collective property arguments, and are especially suspicious when applied to former democratic leaders (as I illustrate through a detailed discussion of Gerald Ford's decision to pardon Nixon following Watergate). I then turn once again to more extreme situations - featuring fragile transitions from authoritarianism to democracy - where the pragmatic benefits of shielding authoritarian criminals from the reach of the law are clear. Here too, I show how the two collectivist frameworks can help us adjudicate conflicting moral impulses - whether with regard to the criminal liability of former despots and their henchmen, or with regard to post-authoritarian truth commissions and associated questions about the importance of transparency and truthfulness in public life.

Chapter 4 turns to another politically salient divide - this time, the divide between 'the people' and 'outsiders.' I examine this divide by adopting an international perspective on the corruption and abuse of power problems that chapter 3 investigates in the domestic realm. More specifically, I zoom in on customary international practices which allow kleptocrats to accumulate sovereign debt in their peoples' name, regardless of how they came to power and how they exercise it. I show how collective property and collective integrity ideas support some of the best existing proposals for reforming this customary practice. But I also show how the two collectivist frameworks yield novel proposals, such as a public democratic offer of exile to kleptocrats, conditioned on their forfeiture of their illicit assets. I explain (among other things) how proposals of this sort align not only with the value of public honesty, but also with the decency that I associate with collective integrity all this, even though such proposals require of liberal democracies to associate with thoroughly reprehensible criminals.

Finally, chapter 5 turns to another political divide that often explains the hesitation to speak about 'the people' as a unified collective agent: the divide that stems from ethnic and religious cleavages separating different groups within 'the people.' Taking up the case of Israel, I show how the collectivist frameworks can be of use even in stark circumstances where the effects of such cleavages have been acute, and even when these cleavages feed into extremely fraught divides between 'the people' and outsiders. I argue that the collective property and collective integrity frameworks can cast a distinctive light on Israel's ethnic and religious divisions, which have been largely overlooked by political theorists. I then explain why progress with 
regard to these internal divisions might facilitate positive change in the much more familiar context of the Israeli-Palestinian conflict. Finally, I use the historical elements of the integrity framework to explain why Israeli society has especially weighty and stringent duties to support refugees, and use this framework to consider how widespread demographic and social processes shape future hopes for progressive civic engagement in the country.

\section{Disclosure statement}

No potential conflict of interest was reported by the author.

\section{Notes on contributor}

Shmuel Nili is an Assistant Professor of political science at Northwestern University, and a research fellow at the Australian National University's School of Philosophy. He has published widely in leading journals in political science and philosophy. He is currently writing his third book, on what political philosophy might contribute in the face of obvious moral failures in public life. 